\title{
INVESTIGATION ON STRESS-RUPTURE BEHAVIOR OF A CHOPPED-GLASS- FIBER COMPOSITE FOR AUTOMOTIVE DURABILITY DESIGN CRITERIA
}

\author{
Weiju Ren* \\ Metals and Ceramics Division \\ Oak Ridge National Laboratory \\ Oak Ridge, TN 3783 1-6155
}

\begin{abstract}
Practical and inexpensive testing methods were developed to investigate stress-rupture properties of a polymeric composite with chopped glass fiber reinforcement for automotive applications. The material was tested in representative automotive environments to generate experimental data. The results indicate that environments have substantial effects on the stressrupture behavior. The data were analyzed and developed into stress-rupture design criteria to address one of the durability aspects of the material for automotive structural applications
\end{abstract}

Keywords: polymeric composite; automobile; stress-rupture; environmental effects; durability.

\section{Introduction}

In searching for structural materials for light-weight and fuel-efficient automobiles, fiberreinforced polymeric composites are considered as promising candidates for applications such as floor pans, body side frames, cross-members and front structural members [1-4]. Despite the

\footnotetext{
* Present affiliation: Air Force Research Laboratory, Room 23, Building 655, 2230 Tenth Street, Wright-Patterson Air Force Base,
} Ohio 45433-7817, U. S. A., Fax:937-656-4840, Email:Weiju.Ren@afit.af.mil 
great potential, one of the concerns of the Automotive Composites Consortium is the durability of the materials [5]. An automobile is generally designed for a service life of 15 years, during which the materials are subjected to sustained and cyclic loading, exposed to temperature changes and various hinds of fluids. These factors may significantly affect the stress-rupture strength of the materials. The present investigation is a part of the U. S. Department of Energy Advanced Automotive Materials project "Durability of Lightweight Composite Structures for Automotive Applications". The primary goal of this investigation is to develop experimentally based stressrupture design guidelines to assure the 15 year long-term integrity of polymeric composite automotive structures.

\section{Material}

The material was a polymeric composite with a urethane-based matrix reinforced by 28.9 vol\% of $50 \mathrm{~mm}$ chopped E-glass fibers. The matrix was identified as Baydur 420 IMR produced by Bayer Corporation. The IMR denotes "internal mold release". The chopped fiber preform was made by the $\mathrm{P} 4$ process recently developed by Owens-Corning in Battice, Belgium. The matrix consisted of polyol and polymeric isocyanate with an amine coreactant to produce a crosslinked urea-urethane basic structure. The urea component contributes to the heat resistance of the final composite structure. The matrix was produced via the Structural Reaction Injection Molding (SRIM) process in which the two reactive streams, polyol and polymeric isocyanate, were pumped at high pressure into an impingement mixing chamber to quickly produce a uniform mixture of the components. The reacting mixture was then pumped into a closed mold containing the reinforcement. The reaction time necessary to transform the liquid chemical reactants into the

Oak Ridge National Laboratory, managed by UT-Battelle, LLC, for the U. S. Department of Energy under contract DE-AC05OOOR22725. 
solid resin matrix was of the order of 15 - 20 seconds. Detailed information about the material can be found in reference [6].

\section{Test matrix}

Automotive materials are subjected to various service environments including cold and hot weather, engine heat, dry air in deserts, damp air in coastlands, exposure to fluids in a rain or car wash, spill of coolant, windshield washer fluid, brake fluid, motor oil, and battery acid, plus motor vibration and low frequency load cycling on rough roads. The test matrix of the present investigation was designed to simulate the representative service environments, which were selected as "necessary for testing" by narrowing down from the more extensive list of automotive environments studied in a previous investigation on a reference material $[4,7]$. The representative environments included air with a nominal $50 \%$ relative humidity (air/50\%RH), distilled water immersion, windshield washer fluid immersion and battery acid splatter. The test stress ranged from compressive $125 \mathrm{MPa}$ to tensile $155 \mathrm{MPa}$, while the test temperature ranged from -40 to $120^{\circ} \mathrm{C}$, but not in all environments. Also included were tests under static tension with superimposed cyclic tensile loading to study the effects of rough roadway condition. A total of 131 creep tests were conducted, among which 73 reached the rupture point to provide information on stress-rupture behavior.

\section{General Experimental Procedures and Data Reduction}

For tests under tension, dogbone shape specimens were utilized, and the nominal size was 203.2 x 25.4 x $3.18 \mathrm{~mm}$ with a $20.3 \mathrm{~mm}$ wide gage section. For tests under compression, short tablet specimens were employed with a nominal size of $31.75 \times 25.4 \times 3.18 \mathrm{~mm}$, The shortened 
length was designed to prevent buckling, and both ends of the specimen were machined parallel to each other to ensure a uniform stress distribution when compressed.

The tests were conducted in lever-arm creep machines. Reliable and inexpensive grips were developed to hold the specimens during testing. For tensile loading, the specimen was held by two $38.1 \mathrm{~mm}$ long segments of a curved tooth file, which were clamped using stainless steel plates with a slot to limit the travel of the file segment. Four screws were torqued to a set value to hold these components together firmly. The stainless steel plates were attached to pull stringers with steel pins. For compressive loading, each end of the specimen was seated snugly in a $6.35 \mathrm{~mm}$ deep slot along the center line of a stainless steel anvil of $25.4 \times 25.4 \times 9.53 \mathrm{~mm}$. The two anvils were compressed between two parallel heavy discs. The bottom disc was attached to the top pull rod and the top disc to the bottom pull rod to produce a compressive load on the specimen. Because the mechanical response of the material is sensitive to loading rate, all specimens were loaded at a constant nominal strain rate of $0.04 / \mathrm{min}$. $\left(6.7 \times 10^{-4} / \mathrm{s}\right)$.

Because data scatter is commonly found in polymeric composites, mostly resulting from local variation of fiber content, the testing stress values in the present investigation were multiplied with a normalization factor in data reduction process to minimize the data scatter as follows:

$$
\text { normalized stress }=\text { testing stress } \times\left(E_{\text {average }} / E_{\text {specimen }}\right)
$$

where

$\mathrm{E}_{\text {specimen }}=$ Young's modulus of the specimen in air at $23^{\circ} \mathrm{C}$, $\mathrm{E}_{\text {average }}=$ average Young's modulus of the material in air at $23^{\circ} \mathrm{C}$. 
An average Young's modulus value of $11.7 \mathrm{GPa}$ was used. The normalized stress values, which may appear slightly different from the original testing stress values discussed in the text, are used in all the figures of this paper.

Some experimental and data reduction details for specific representative environments will be described in the corresponding part in the following Results and Discussion section.

\section{Results and Discussion}

\subsection{Failure under tensile stresses}

5.1.1. Failure in air with $50 \%$ relative humidity at room temperature under tension

Creep-rupture data resulting from tests conducted in lab ambient air at room temperature $\left(23^{\circ} \mathrm{C}\right)$ were analyzed and used as the baseline, with which results from the other environments were compared, It should be pointed out that the lab ambient air was roughly controlled only for temperature but not for humidity. Lab humidity monitor indicated that the daily relative humility varied from approximately $30 \%$ in the winter to about $70 \%$ in the summer months, yielding an annual average around 50\% relative humidity $(50 \% \mathrm{RH})$. Since each test was completed in a short period of time (from hours to several months) and covered various dates of the year, on average they should have normalized the daily humidity variations. In the present investigation, the baseline condition, i. e., the lab ambient air at room temperature $\left(23^{\circ} \mathrm{C}\right)$ with an annual average of $50 \%$ relative humidity, is referred to as $\mathrm{Air} / 50 \% \mathrm{RH} 23 \mathrm{C}$ for the reason of convenience.

A total of twenty-nine specimens from three plaques, B2, B3, and B9, were tested in the baseline condition. Of these 29 tests, 12 reached rupture, providing stress-rupture information for developing design curves and equations. 
The baseline data are presented in Fig. 1 . The curve designated "Air $/ 50 \% \mathrm{RH} 23^{\circ} \mathrm{C} / \mathrm{Avg}$ " was derived by a least-squares fit to represent the average stress-rupture behavior of the material in the baseline condition, The minimum stress-rupture curve (dash curve) labeled “Air $/ 50 \% \mathrm{RH} 23^{\circ} \mathrm{C} / \mathrm{Min}$ " was obtained essentially by a parallel graphical shift of the average curve downward to be a lower bound for all the data points. It is intended to represent the highest stress that may not cause rupture for a given time. The average and minimum curves for Air $/ 50 \% \mathrm{RH} 23^{\circ} \mathrm{C}$ will be used as the basis for comparison with results from the other testing conditions. Another curve in Fig. 1 marked “Air/50\%RH23 ${ }^{\circ} \mathrm{C} / \mathrm{MDAS}$ ”, in which MDAS stands for "maximum design allowable stress", is the minimum curve multiplied by a factor of 0.8 on stress. Equations for the average and minimum stress-rupture and maximum design allowable stress curves are also presented in Fig. 1. They all have the form:

$$
\sigma=\mathrm{Bt}^{\mathrm{m}}, \text { for } \mathrm{t} \geq 10 \mathrm{~h} \text {. }
$$

Throughout this paper, data from various testing conditions will be converted into curves represented by eqn (2) with specific values of $\mathrm{B}$ and $\mathrm{m}$. These curves and equations are recommended for the derivation of alternate design guidelines if desired.

It should be stressed that application of all the curves and eqn (2) developed in this paper is limited to stress-rupture times not less than $10 \mathrm{~h}$. This constraint is intended to eliminate the undue effects of short times before environments, considered later in this paper, have their full effects. The detailed procedures for developing curves and equations in Fig. 1 are the same as discussed in a previous investigation for the reference material [7]. 


\subsubsection{Temperature effect in air under tension}

The temperature effect on stress-rupture in air was investigated at $-40,50$ and $120^{\circ} \mathrm{C}$. For tests at $-40^{\circ} \mathrm{C}$, the specimen was contained in a chamber cooled with liquid nitrogen vapor flow controlled by a closed-loop temperature control system. For 50 and $120^{\circ} \mathrm{C}$, three thermocouples were attached to the specimen gage section using glass tape, and a piece of metal conductive plate having dimensions of $101.6 \times 25.4 \times 3.18 \mathrm{~mm}$ was placed on each side of the specimen gage section to ensure uniform heating. A heating tape was wound over the metal plates and then wrapped with fiberglass insulation cloth.

Figure 2 compares the stress-rupture data at $-40,50$ and $120^{\circ} \mathrm{C}$ with those at $23^{\circ} \mathrm{C}$. Because of the difficulties in maintaining long-term tests at $-40^{\circ} \mathrm{C}$, the tests were accidentally terminated before rupture occurred. Nevertheless, Fig. 2 clearly indicates that the material has at least equal, and most likely higher, stress-rupture strength at $-40^{\circ} \mathrm{C}$ compared to that at $23^{\circ} \mathrm{C}$. Therefore, the minimum stress-rupture curve, the maximum design allowable stress curve and its equation for $23^{\circ} \mathrm{C}$ are considered safe for $-40^{\circ} \mathrm{C}$ design.

At $50^{\circ} \mathrm{C}$, limited data indicate that the average rupture stress is equal to, or may become just slightly lower than, that at $23^{\circ} \mathrm{C}$ after a long time. Again, it is convenient and practical to use the minimum stress-rupture curve and the maximum design allowable stress curve and its equation at $23^{\circ} \mathrm{C}$ for $50^{\circ} \mathrm{C}$.

Significant decrease in the stress-rupture strength is obvious in Fig. 2 at $120^{\circ} \mathrm{C}$. Calculation indicated that the minimum stress-rupture strength at $120^{\circ} \mathrm{C}$ was approximately $26 \mathrm{MPa}$ lower than that at $23^{\circ} \mathrm{C}$. The minimum stress-rupture curve and the maximum design allowable stress curve for $120^{\circ} \mathrm{C}$ are labled "Air $120^{\circ} \mathrm{C} / \mathrm{Min}$ " and "Air $120^{\circ} \mathrm{C} / \mathrm{MDAS}$," respectively, in Fig. 2 along with the maximum design allowable stress equation for $120^{\circ} \mathrm{C}$. 
In a parallel investigation on creep deformation behavior of the same composite, the material demonstrated significant tertiary creep behavior at $120^{\circ} \mathrm{C}$ [8]. Because tertiary creep can accumulate considerable amount of deformation in a relatively short period of time, it is normally treated with great caution or completely avoided for dimensional stability concerns, Figure 3 compares the tertiary creep initiation time with its stress-rupture time if the specimen was tested to rupture. The hollow and filled triangle symbols in Fig. 3 indicate that at high stresses the initiation of tertiary creep was closely followed by rupture, therefore it should not constitute a dimensional stability problem when stress-rupture criterion is employed in design. At low stresses of 25 to $75 \mathrm{MPa}$, however, tertiary creep commenced after about $4,600 \mathrm{~h}$ of testing under continuous load at $120^{\circ} \mathrm{C}$ without immediate rupture followed. Instead, the high creep rate continued for about another $2,000 \mathrm{~h}$ and then started to decelerate to a steady-state creep rate. However, since the design operating life for an automobile is ACCUMULATIVELY 3,000 to $5,000 \mathrm{~h}$, the tertiary creep initiation that may occur after more than $4,000 \mathrm{~h}$ of CONTINUOUS heating and load bearing should not be considered as a serious problem from a stress-rupture point of view.

In summary, the recommended maximum design allowable stresses at various temperatures are calculated and listed in Table 1 for specific no-rupture time limits using eqn (2) with the appropriate $\mathrm{B}$ and $\mathrm{m}$ values.

\subsubsection{Environmental effects under tension}

Investigation of environmental effects included distilled water immersion, windshield washer fluid immersion, battery acid splatter, and low-frequency load cycling. The distilled water immersion included tests at 23 and $50^{\circ} \mathrm{C}$ to study the combined effect of water and temperature. 
The distilled water immersion condition was included to also address humidity effects on the stress-rupture behavior of the material, During service, an automotive structural component can be exposed to various humidity conditions including air with relative humidity ranging from less than $10 \%$ to nearly $100 \%$ and even water soak. A previous study [4] showed that a distilled water immersion environment represented the worst of all humidity conditions affecting timedependent mechanical behavior of the reference material, which, like the present chopped fiber composite, had a urethane-based matrix.

During the water immersion test, the specimen was completely submerged in distilled water in the testing chamber. For testing at $50^{\circ} \mathrm{C}$, the water temperature was kept constant and uniform with a feedback-controlled immersion heater and an electrical stirrer. To replenish the water evaporated, a reliable and inexpensive, atmosphere activated compensation system was developed to automatically refill the chamber whenever the water decreased to a preset level [4].

Prior to being tested in distilled water, the specimens were presoaked in distilled water for either a long term or short term. The long-term specimens were presoaked at $50^{\circ} \mathrm{C}$ for $2,160 \mathrm{~h}(3$ months), while the short-term ones at $23^{\circ} \mathrm{C}$ for $100 \mathrm{~h}$. Test results are presented in Fig. 4, which shows the stress-rupture data and the corresponding average stress-rupture curves for the two presoak conditions compared to those for air $/ 50 \% \mathrm{RH}$. Note that all of the specimens were tested in distilled water at $23^{\circ} \mathrm{C}$. Obviously, the water presoaking deteriorated stress-rupture strength, the longer the presoak and the higher the presoak temperature, the lower the stress-rupture strength. It can be noted that the average stress-rupture curves for the short- and long-term presoaks are approximately parallel to each other. From water immersion tensile tests with a $1,000 \mathrm{~h}$ presoak at $23^{\circ} \mathrm{C}$ [9], it is known that the UTS of the presoaked specimens is 0.91 that of the baseline UTS. Based on the above information, the short-term curve is scaled downward to 
0.91 as a prediction for the average stress-rupture curve for water immersion with a 1,000 $\mathrm{h}$ presoak at $23^{\circ} \mathrm{C}$. The minimum stress-rupture curve' and maximum design allowable stress curve for the short- and long-term presoaks are developed and presented in Fig. 5.

The combined effects of test temperature and water on the stress-rupture life of specimens with the long-term $50^{\circ} \mathrm{C}$ presoak are shown in Fig. 6 . Examination based on the open symbols for the specimens tested at $23^{\circ} \mathrm{C}$ and the filled symbols for the specimens tested at $50^{\circ} \mathrm{C}$ indicates that increasing the test water temperature from $23 \mathrm{C}$ to $50^{\circ} \mathrm{C}$ slightly lowered the stress-rupture strength, but the indication was somewhat not conclusive. All the data for $50^{\circ} \mathrm{C}$ are still bounded by the minimum stress-rupture curve for $23^{\circ} \mathrm{C}$. Because continuous load bearing in water at $50^{\circ} \mathrm{C}$ after a long-term presoak at $50^{\circ} \mathrm{C}$ is an unlikely service condition for automotive structural components, the minimum stress-rupture curve, maximum design allowable stress curve and its equation established for the specimens with long-term presoak tested in water at $23^{\circ} \mathrm{C}$ are recommended for $50^{\circ} \mathrm{C}$.

For windshield washer fluid exposure effect, a simulated washer fluid was employed to avoid subtle variations in commercial products. The simulated fluid was made of 70 vol\% pure methanol plus 30 vol\% distilled water. Specimens were presoaked in the fluid for $100 \mathrm{~h}$ at $23^{\circ} \mathrm{C}$. The test results are presented in Fig. 7, which shows that the data points are comparable to those for water immersion with the short-term presoak. The two points with arrows represent on-going tests when they were terminated for data processing. Although the three ruptured data points for windshield washer fluid suggest that the windshield washer fluid may be more deleterious than water, long-term immersion in windshield washer fluid under load is an unlikely situation for automotive structural components. Therefore, the minimum stress-rupture curve and the 
maximum design allowable stress curve for water immersion with short-term presoak are suggested for windshield washer fluid exposure for practical design purposes.

The battery acid splatter condition was simulated using a solution of $35 \mathrm{wt} \%$ sulfuric acid plus $65 \mathrm{wt} \%$ distilled water to again avoid subtle commercial variations in commercial products. The specimen was prepared by placing about $3 \mathrm{~cm} 3$ of the solution on the virgin surface and then heating it at $66^{\circ} \mathrm{C}$ for $24 \mathrm{~h}$ so that absorption occurred. The test results are presented in Fig. 8, which indicates that stress-rupture strength for battery acid splatter may be slightly lower than, but still comparable to, that for water immersion with the long-term presoak. Since battery acid splatter is a feasible condition for automotive structural components, the minimum stress-rupture curve, maximum design allowable stress curve and its equation were developed and are presented in Fig. 8. Note that the curves and equation were developed based on ruptured data points excluding the two on-going points marked with arrows.

Low-frequency load cycling tests in air were conducted to simulate accelerations, sharp turns and rough roadway conditions. A creep-fatigue loading condition was created by imposing a cyclic load to the creep machine through a pneumatic piston. The previous study on the reference material indicated that motor vibration was less damaging than low-frequency load cycling. Therefore, it can be covered by the low-frequency load cycling condition for design purposes [4]. The minimum-to-maximum stress ratio $\left(\sigma_{\min } / \sigma_{\max }\right)$ of 0.5 , and the frequency of 30 cycles per minute were used in the low-frequency load cycling tests. The test results are given in Fig. 9, which shows that the rupture stresses under low-frequency cyclic loading in air are comparable to those for water immersion with the long-term presoak. Therefore, the minimum stress-rupture curve, the maximum design allowable stress curve and its equation for water immersion with the long-term presoak are suggested for considering low-frequency load cycling effects in design. 
Here, as throughout this study, there may be synergisms (e.g., an interaction between water effects and load cycling effects).

The recommended maximum stress-rupture design allowable stresses for the above representative environments are calculated and listed in Table 2 for specific no-rupture time limits using eqn (2) with the appropriate B and $\mathrm{m}$ values.

\subsection{Failure under compressive stresses}

5.2.1. Failure in air with $50 \%$ relative humidity at room temperature under compression

Test results for compressive loading in $\mathrm{Air} / 50 \% \mathrm{RH} 23^{\circ} \mathrm{C}$ are presented in Fig. 10. The limited data suggest that stress-rupture behavior under compression is comparable to that under tension. Therefore, the minimum stress-rupture curve, maximum design allowable stress curve and its equation for tension are recommended for compressive loading. The recommended maximum design allowable stresses for compressive loading in Air $/ 50 \% \mathrm{RH} 23^{\circ} \mathrm{C}$ are calculated and listed in Table 3 for specific no-rupture time limits using eqn (2) with the appropriate B and m values.

\subsubsection{Temperature effect in air under compression}

Figure 11 shows how temperature combined with compression affects the stress-rupture strength. The two solid lines at the top represent the average and minimum rupture stresses in the baseline condition, i.e., Air $/ 50 \% \mathrm{RH} 23^{\circ} \mathrm{C}$ under tension. Changing stress from tension to compression did not obviously affect the stress-rupture strength, as indicated by the filled triangles for compression at $23^{\circ} \mathrm{C}$. Increasing temperature to $120^{\circ} \mathrm{C}$ under tension lowered the stressrupture strength below the minimum curve, as indicated by the crossed squares. Then changing the stress from tension to compression brought the stress-rupture strength significantly down as 
indicated by the filled circles. The combination of temperature and compressive loading may have induced matrix shear and fiber buckling mechanisms, which can greatly deteriorate stress-rupture strength.

The minimum stress-rupture curve, maximum design allowable stress curve and its equation for air at $120^{\circ} \mathrm{C}$ under compression are given in Fig. 11. The recommended maximum design allowable stresses for compressive loading in air at $120^{\circ} \mathrm{C}$ are calculated and listed in Table 3 for specific no-rupture time limits using eqn (2) with the appropriate B and $\mathrm{m}$ values.

\subsubsection{Environmental effects under compression}

The investigation of environmental effects under compression included water immersion at 23 and $50^{\circ} \mathrm{C}$, both with long-term presoak at $50^{\circ} \mathrm{C}$, and air with battery acid splatter at $23^{\circ} \mathrm{C}$.

Results for water immersion tests at $23^{\circ} \mathrm{C}$ under compression are given in Fig. 12. Obviously, the stress-rupture behavior under compression is comparable to that under tension. Therefore, the minimum stress-rupture curve, maximum design allowable stress curve and its equation for tension are suggested for compression.

The effect of water temperature under compression is shown in Fig. 13, which indicates that compression at $50^{\circ} \mathrm{C}$ in distilled water slightly decreased the stress-rupture strength. However, since all of the $50 \mathrm{C}$ compression data points are still bounded by the minimum stress-rupture curve for tension at $23^{\circ} \mathrm{C}$, and a continuous compressive load in water at $50^{\circ} \mathrm{C}$ after a long-term presoak is an unlikely automotive service condition, the minimum stress-rupture curve, maximum design allowable stress curve and its equation for tension at $23^{\circ} \mathrm{C}$ are recommended.

Test results for battery acid splatter under compression are shown in Fig. 14. Contrary to the trend observed earlier, the stress-rupture strength under compression is higher than that under 
tension. Normally, stress-rupture strength is lower under compression than tension because of additional failure mechanisms such as matrix shearing and fiber buckling. Further strength degradation can be induced by the presence of corrosive liquid or moisture penetrating microcracks under compression. Analysis of the testing process reveals that this abnormal behavior under compression as shown in Fig. 14 originated from changes of the moisture content in the specimen. Both tension and compression specimens were prepared for battery acid splatter with the same procedure at the same time, but the compression specimens were tested at a much later time when the testing facilities became available. Because sulfuric acid was a good absorbent of moisture, the surface of freshly prepared specimens tested in tension were covered with a thin layer of corrosive liquid formed by the acid and moisture absorbed from the surrounding atmosphere. Under load, this corrosive liquid was believed to have penetrated into microcracks of the specimen and thus lowered the rupture strength. Unfortunately, compression testing facility was not available until several months later when the specimens became completely dried. Without the presence of the corrosive liquid, the compressive stress-rupture strength recovered somewhat as indicated in Fig. 14. However, the damage of battery acid splatter to stress-rupture strength is still visible when the compressive data are compared with the virgin material data shown in Fig. 14. It appears that the most damaging time is right after the battery acid splatter and absorption. As the material dries up with the elapse of time, the weakened stress-rupture strength partially recovers.

In addition to the maximum design allowable stresses given in Tables 1-3, stress reduction factors for the above representative environments were also developed for engineering design purposes in Table 4. These stress reduction factors were derived by dividing the stresses in 
Tables $1-3$ by those in the row for $23^{\circ} \mathrm{C}$ in Table 1, i.e., the maximum design allowable stresses in Air $/ 50 \% \mathrm{RH} 23^{\circ} \mathrm{C}$ for specific no-rupture time.

To further provide a clear picture of the environmental effects on stress-rupture strength, all the recommended maximum design allowable stress curves are compared in Fig. 15. The T and C in parentheses stand for tension and compression respectively. The dash curve was not directly derived from stress-rupture test results, but predicted based on stress-rupture and tensile test results as previously discussed in Fig. 4. Note the time limits for specific environments in Tables 1-3 are not presented in Fig. 15 due to the limited space.

\section{Summary and Discussion}

For tensile loading, the design allowable stresses for various temperatures and times are given

in Table 1. In Table 4 the effects of various fluid conditions, temperature, and compressive loading on the basic room temperature tensile allowable stresses are shown in the form of rupture stress reduction factors. For the conditions examined, the reduction factors for tension and compression differ only in the $120^{\circ} \mathrm{C}$ air case. In an investigation on tensile properties of the material, two fluid conditions have been adopted as practical bounding conditions [9]:

1. Room temperature water immersion with a $1,000 \mathrm{~h}$ presoak at room temperature.

2. Room-temperature windshield washer fluid immersion with a $100 \mathrm{~h}$ presoak at room temperature.

Of these two, Table 4 indicates water immersion to be most degrading to stress-rupture strength. The stress reduction factors for water immersion are listed in Table 5.

Results from the investigation on tensile properties indicate that the corresponding reduction factor for the UTS $(0 \mathrm{~h})$ is 0.91 , which is consistent with the values tabulated in Table 5. 
Figure 16 compares the stress-rupture strength of the chopped fiber composite with that of the reference material studied in the previous investigation $[7 \& 10]$. The average rupture stress for the chopped fiber composite is approximately $30 \mathrm{MPa}$ higher than that for the reference material in air with $50 \% \mathrm{RH}$ at $23^{\circ} \mathrm{C}$. Some selected environmental effects on the rupture stresses of the two materials are compared in Fig. 17 based on their respective rupture stress reduction factors. It should be pointed out that the reduction is relative to each material's own baseline stress. Obviously, the chopped fiber composite is less vulnerable to environmental degradation than the reference material when stress-rupture strength is considered.

\section{Acknowledgments}

W. Ren would like to thank Dr. Charles Brinkman, Dr. James Corum and Mr. Christopher Stevens for their support to this investigation; Dr. James Corum and Dr. Ken Liu for reviewing this paper. This research is sponsored by the U. S. Department of Energy, Assistant Secretary for Energy Efficiency and Renewable Energy, Office of Transportation Technologies, as part of the Advanced Automotive Materials Program.

\section{References}

1. Corum J., Ruggles M., Battiste R. L., Simpson W. A., McCoy H. E. and Weitsman Y. J., Durability of composites in automotive structural applications. Annual Automotive Technology Development Customers Coordination Meeting Vol. II: Automotive R\&D Poster Session. 1996. 3 13-327.

2. Karger-Kocsis, J., Environmental stress corrosion behavior of polyamides and their composites with short glass fibers and glass swirl mat. Polymer Bulletin. 1991. 26: 123-130. 
3. Karger-Kocsis, J. and Fejes-Kozma Zs., Damage zone development and failure sequence in glass fiber mat-reinforced polypropylene under static loading conditions. Mechanics of Composite Materials, 1994. 20(1):\%13.

4. Ren W. and Brinkman C. R., Creep and creep rupture behavior of a continuous strand, swirl mat reinforced polymer composite in automotive environments. Proceedings of International Composites Expo ‘98, Nashville, TN. January 1998. Session 21-E.

5. Dearlove T. J., Denton D. L., Hager-man E. M., Houston D. and Kakarala S. N., Development of standardized tests for an automotive structural composites database. Proceedings of the 10th Annual ASM/ESD Advanced Composites Conference. 1994. 555-566.

6. Corum J. M. et al., Durability-based design criteria for a chopped-glass-fiber automotive structural composite. ORNL/TM-1999/182, Lockheed Martin Energy Research Corp., Oak Ridge National Laboratory. November 1999.

7. Corum J. M. et al., Durability-based design criteria for an automotive structural composite: part 2. background data and models, ORNL-693 1, Lockheed Martin Energy Research Corp., Oak Ridge National Laboratory. February 1998.

8. Ren- W., Time-dependent deformation modeling for a chopped-glass-fiber composite for automotive durability design criteria, submitted to Composites Science and Technology for publication consideration, 2001.

9. Ruggles M. B., Corum J. M., and Battiste R. L., Effects of Environment on Uniaxial and Biaxial Behavior of a Chopped Fiber Polymeric Composite. submitted to the ASME Journal of Engineering Materials and Technology for publication. 2000. 
10. Corum J. M. et al., Durability-based design criteria for an automotive structural composite: part 1. design rules, ORNL-6930, Lockheed Martin Energy Research Corp., Oak Ridge National Laboratory, February 1998. 
Table 1. Maximum design allowable 'stresses under tension in air for specific no-rupture time limits

\begin{tabular}{|c|c|c|c|c|c|c|c|c|c|c|}
\hline \multirow{3}{*}{$\begin{array}{l}\text { Temperature } \\
\left({ }^{\circ} \mathbf{C}\right)\end{array}$} & \multicolumn{10}{|c|}{$\begin{array}{c}\text { Maximum design allowable stress } \\
(\mathbf{M P a})\end{array}$} \\
\hline & \multicolumn{4}{|c|}{ Hours } & \multicolumn{4}{|c|}{ Years } & \multicolumn{2}{|c|}{ Parameter } \\
\hline & 10 & 1000 & 3000 & 5000 & 1 & 5 & 10 & 15 & B & $\mathrm{m}$ \\
\hline-40 & 100.36 & 93.66 & 92.13 & 91.43 & 90.66 & 88.50 & 87.59 & 87.06 & 103.89 & -0.015 \\
\hline 23 & 100.36 & 93.66 & 92.13 & 91.43 & 90.66 & 88.50 & 87.59 & 87.06 & 103.89 & -0.015 \\
\hline 50 & 100.36 & 93.66 & 92.13 & 91.43 & 90.66 & 88.50 & 87.59 & 87.06 & 103.89 & -0.015 \\
\hline 120 & 79.18 & 71.88 & 70.24 & 69.49 & & & & & 83.1 & -0.021 \\
\hline
\end{tabular}


Table 2. Maximum design allowable stresses under tension in various environments for specific no-rupture time limits

Maximum design allowable stress

(MPa)

\begin{tabular}{lccccccccccc}
\cline { 2 - 10 } \multicolumn{1}{c}{ Environment } & \multicolumn{4}{c}{ Hours } & \multicolumn{4}{c}{ Years } & \multicolumn{3}{c}{ Parameter } \\
\cline { 2 - 10 } , & 10 & 1000 & 3000 & 5000 & 1 & 5 & 10 & 15 & B & $\mathrm{m}$ \\
\hline Water $\mathbf{2 3}^{\circ} \mathbf{C}$, short soak & 82.72 & 65.41 & 61.84 & 60.25 & 58.55 & & & & 93.03 & -0.051 \\
Water $\mathbf{2 3}^{\circ} \mathbf{C}$, $\mathbf{1 0 0 0 - h}$ soak & 75.28 & 59.52 & 56.27 & 54.83 & 53.28 & & & & 84.66 & -0.051 \\
$\quad($ estimated) & & & & & & & & & & \\
Water $\mathbf{2 3}^{\circ} \mathbf{C}$, long soak & 43.40 & 30.17 & 27.66 & 26.56 & 25.41 & & & & 52.06 & -0.079 \\
Water $\mathbf{5 0}^{\circ} \mathbf{C}$, long soak & 43.40 & 30.17 & 27.66 & 26.56 & & & & & 52.06 & -0.079 \\
Windshield washer fluid & 82.72 & 65.41 & 61.84 & 60.25 & 58.55 & & & & 93.03 & -0.051 \\
Battery acid splatter & 39.95 & 25.09 & 22.46 & 21.33 & 20.15 & 17.13 & 15.97 & 15.33 & 50.41 & -0.101 \\
Load cycling & 43.40 & 30.17 & 27.66 & 26.56 & & & & & 52.06 & -0.079 \\
\hline
\end{tabular}


Table 3. Maximum design allowable stresses under compression in various environments for specific no-rupture time limits

\begin{tabular}{|c|c|c|c|c|c|c|c|c|c|c|}
\hline \multirow{3}{*}{ Condition } & \multicolumn{10}{|c|}{$\begin{array}{c}\text { Maximum design allowable stress } \\
(\mathrm{MPa})\end{array}$} \\
\hline & \multicolumn{4}{|c|}{ Hours } & \multicolumn{4}{|c|}{$\mathrm{Ye}$ a $\mathrm{rs}$} & \multicolumn{2}{|c|}{ Parameter } \\
\hline & 10 & 1000 & 3000 & 5000 & 1 & 5 & 10 & 15 & B & $\mathrm{m}$ \\
\hline $\begin{array}{l}\text { Air } 23^{\circ} \mathrm{C} \\
\text { Air } 120^{\circ} \mathrm{C}\end{array}$ & $\begin{array}{r}100.36 \\
25.52\end{array}$ & $\begin{array}{l}93.66 \\
12.97\end{array}$ & $\begin{array}{l}92.13 \\
11.03\end{array}$ & $\begin{array}{l}91.43 \\
10.24\end{array}$ & 90.66 & 88.50 & 87.59 & 87.06 & $\begin{array}{c}103.89 \\
35.8\end{array}$ & $\begin{array}{l}-0.015 \\
-0.147\end{array}$ \\
\hline $\begin{array}{c}\text { Water } 23^{\circ} \mathrm{C} \text {, } \\
\text { long soak }\end{array}$ & 43.40 & 30.17 & 27.66 & 26.56 & 25.41 & & & & 52.06 & -0.079 \\
\hline $\begin{array}{c}\text { Water } \mathbf{5 0 ^ { \circ } \mathrm { C }}, \\
\text { long soak }\end{array}$ & 43.40 & 30.17 & 27.66 & 26.56 & & & & & 52.06 & -0.079 \\
\hline
\end{tabular}


Table 4. Stress reduction factors in representative environments for specific no-rupture time limits

\begin{tabular}{|c|c|c|c|c|c|c|c|c|}
\hline \multirow{3}{*}{ Environment ${ }^{a}$} & \multicolumn{8}{|c|}{ Time } \\
\hline & \multicolumn{4}{|c|}{ Hours } & \multicolumn{4}{|c|}{ Years } \\
\hline & 10 & 1000 & 3000 & 5000 & 1 & 5 & 10 & 15 \\
\hline 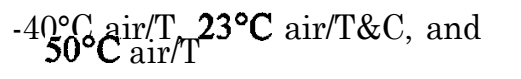 & 1.00 & 1.00 & 1.00 & 1.00 & 1.00 & 1.00 & 1.00 & 1.00 \\
\hline $120^{\circ} \mathrm{C}$ air $/ \mathrm{T}$ & 0.79 & 0.77 & 0.76 & 0.76 & & & & \\
\hline $\begin{array}{c}23^{\circ} \mathrm{C} \text { water, short soak } / \mathrm{T} \text {, and } \\
\text { windshield washer fluid/T }\end{array}$ & 0.82 & 0.70 & 0.67 & 0.66 & 0.65 & & & \\
\hline $23^{\circ} \mathrm{C}$ water, 1000 -h soak $/ \mathrm{T}$ & 0.75 & 0.64 & 0.61 & 0.60 & 0.59 & & & \\
\hline $23^{\circ} \mathrm{C}$ water, long soak $/ \mathrm{T} \& \mathrm{C}$ & 0.43 & 0.32 & 0.30 & 0.29 & 0.28 & & & \\
\hline $\begin{array}{l}50^{\circ} \mathrm{C} \text { water, long soak } / \mathrm{T} \text {; load } \\
\text { cycling/T; and } 50^{\circ} \mathrm{C} \text { water, long } \\
\text { soak/C }\end{array}$ & 0.43 & 0.32 & 0.30 & 0.29 & & & & \\
\hline Battery acid splatter/T & 0.40 & 0.27 & 0.24 & 0.23 & 0.22 & 0.19 & 0.18 & 0.18 \\
\hline $120^{\circ} \mathrm{C}$ air $/ \mathrm{C}$ & 0.25 & 0.14 & 0.12 & 0.11 & & & & \\
\hline
\end{tabular}

$a_{\mathrm{T}}=$ tension, $\mathrm{C}=$ compression. 
Table 5. The stress reduction factors for water immersion

\begin{tabular}{lc} 
Time & Reduction factor \\
\hline $\mathbf{1 0 ~} \mathbf{h}$ & 0.75 \\
$\mathbf{1 0 0 0} \mathbf{h}$ & 0.64 \\
$3000 \mathrm{~h}$ & 0.61 \\
$5000 \mathrm{~h}$ & 0.60 \\
1 year & 0.59
\end{tabular}




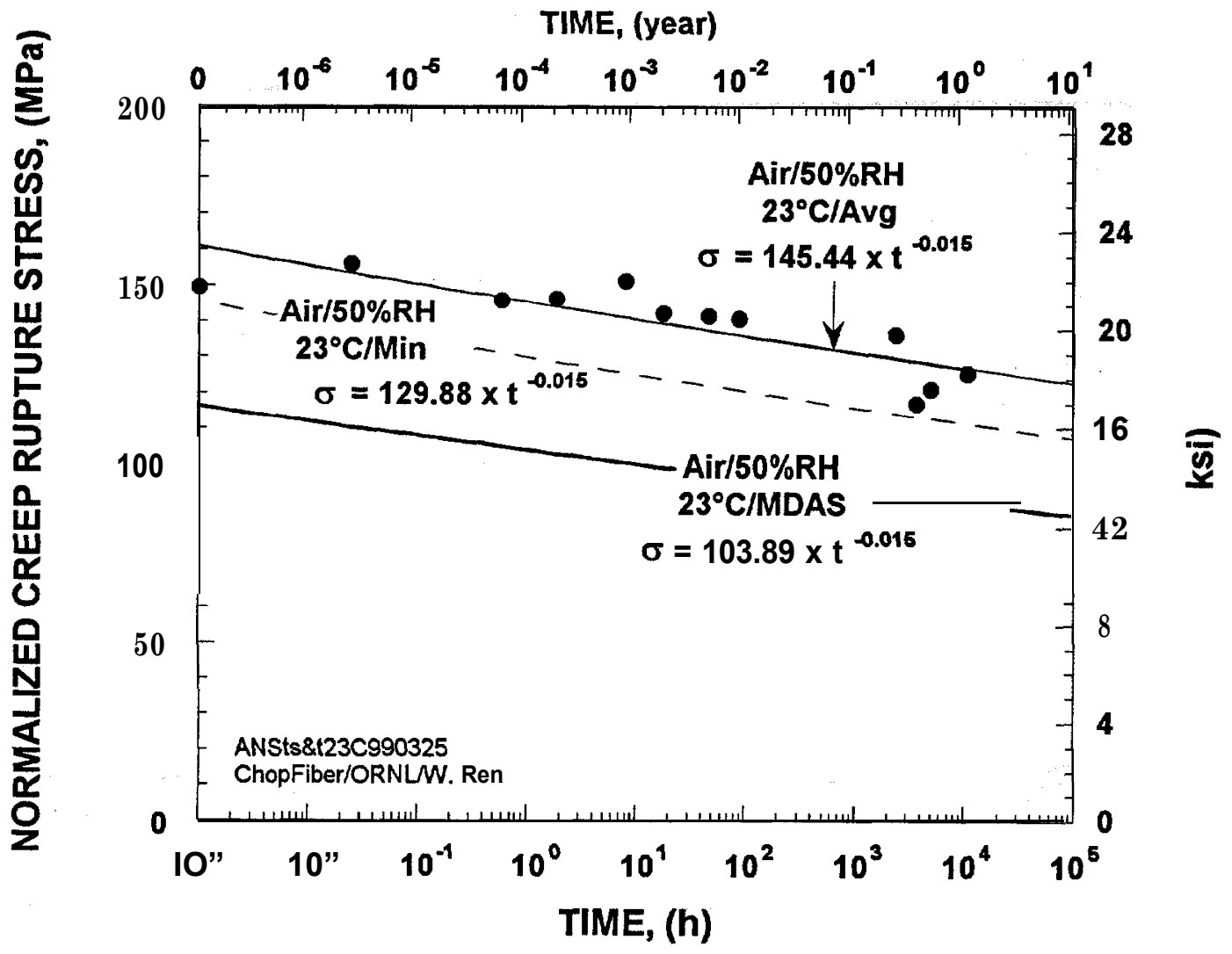

Fig. 1. Stress-rupture data and curves and equations for the baseline condition. 


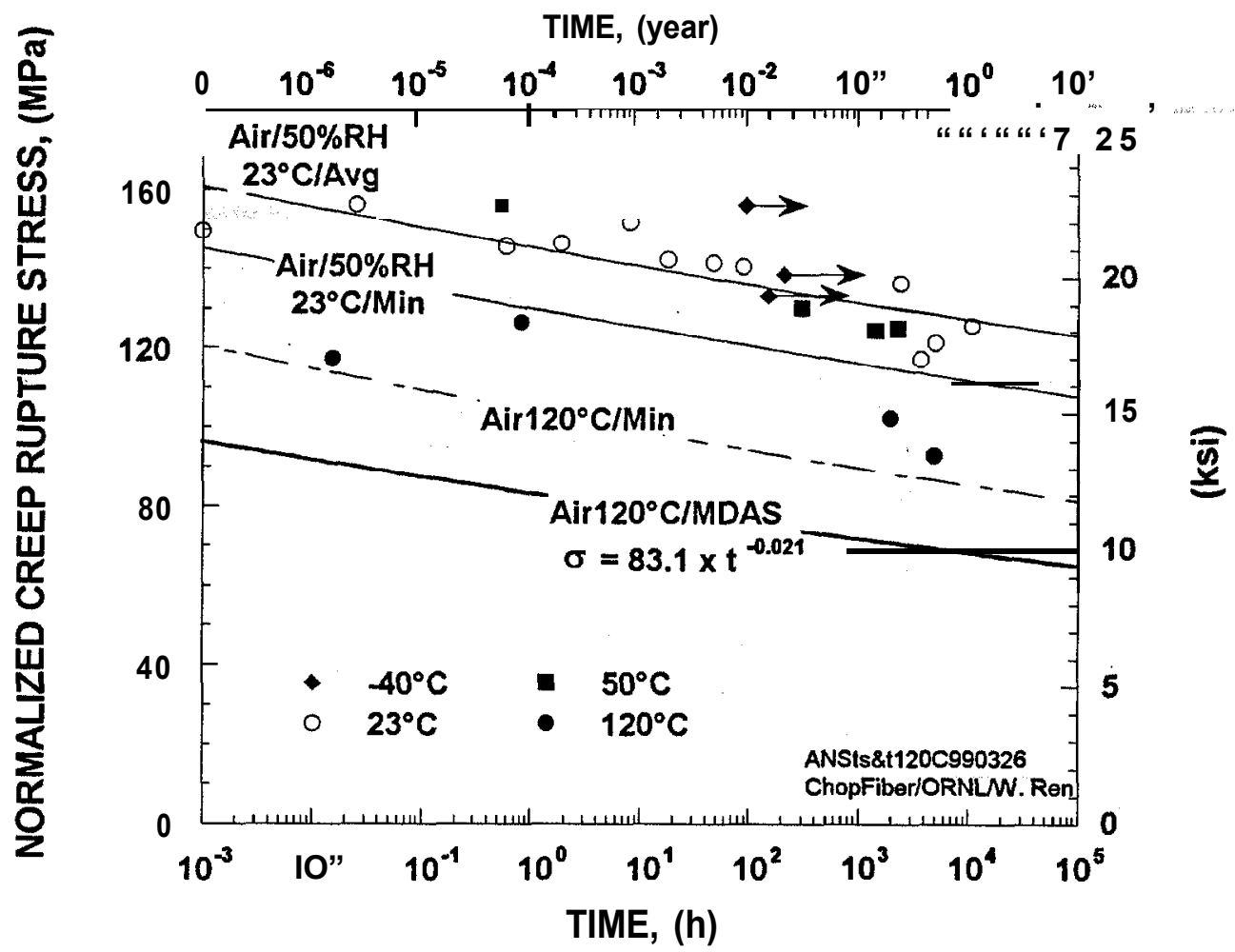

Fig. 2. Stress-rupture data in air at various temperatures, with minimum stress-rupture curve, maximum design allowable stress curve and its equation for $120^{\circ} \mathrm{C}$. 


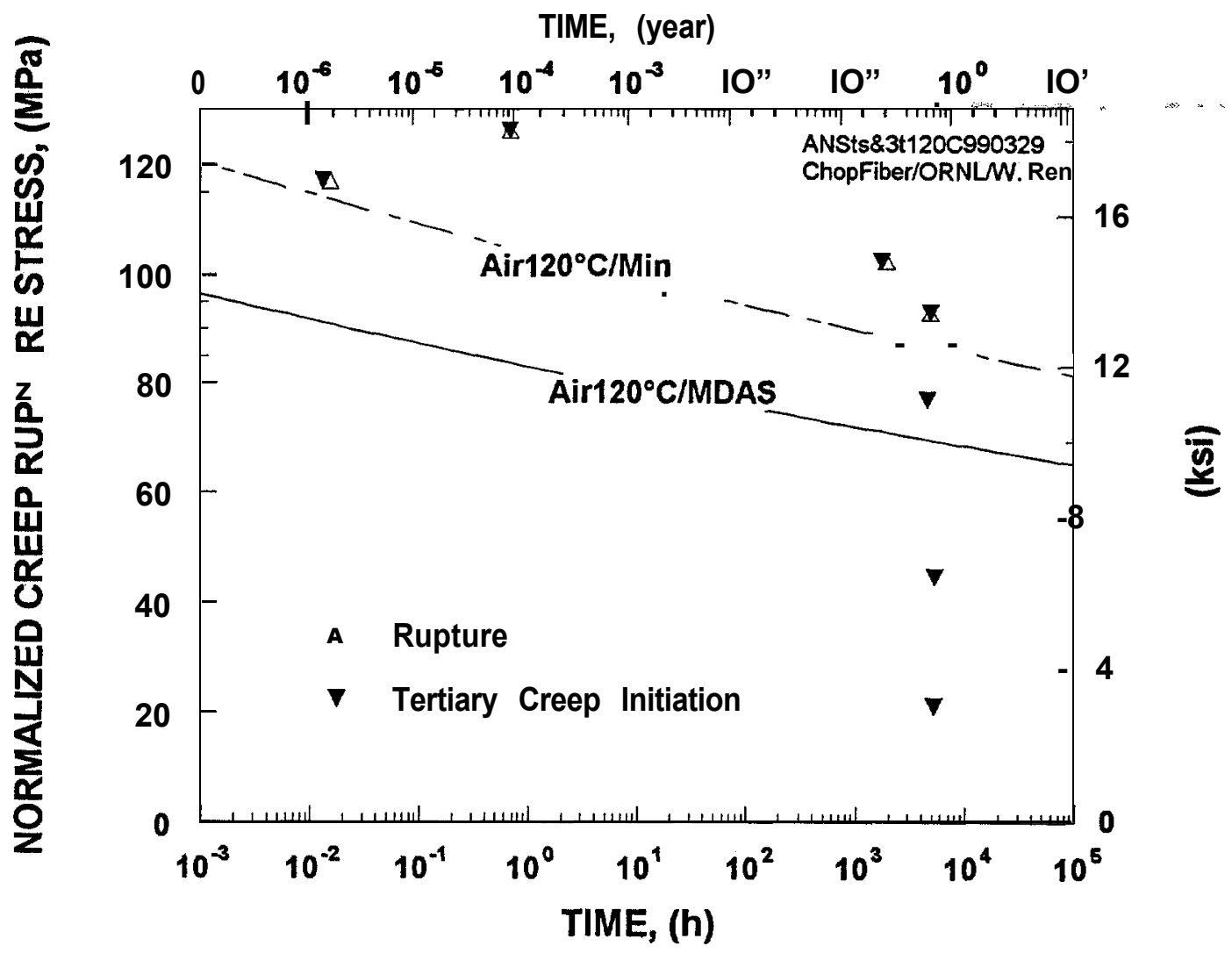

Fig. 3. The initiation of tertiary creep compared to stress-rupture at $120^{\circ} \mathrm{C}$. 


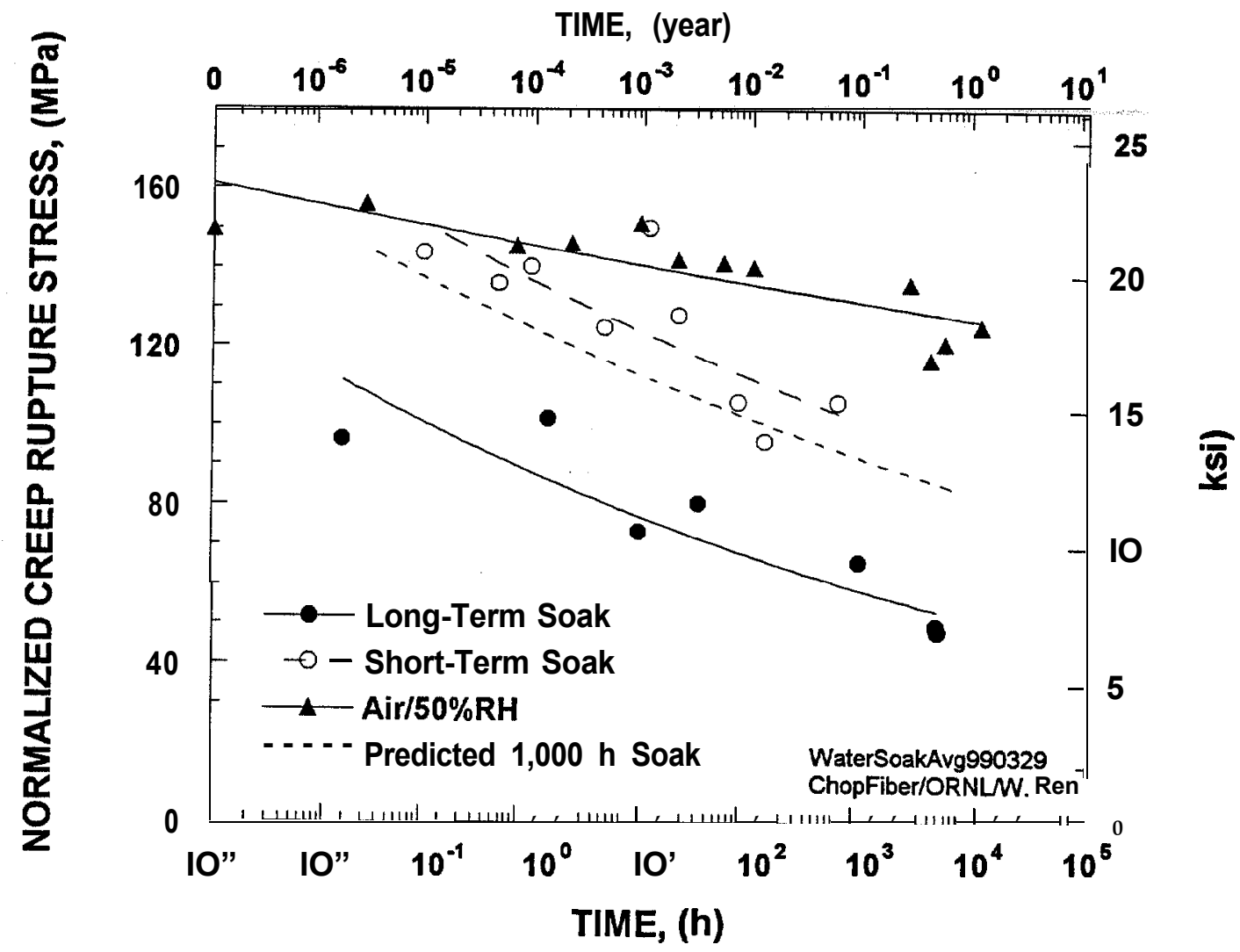

Fig. 4. Stress-rupture data and average rupture curves in distilled water at $23^{\circ} \mathrm{C}$ with long-term $(2,160 \mathrm{~h}) 50^{\circ} \mathrm{C}$ presoak, short-term $(100-\mathrm{h}) 23^{\circ} \mathrm{C}$ presoak, and in air $/ 50 \% \mathrm{RH}$. 

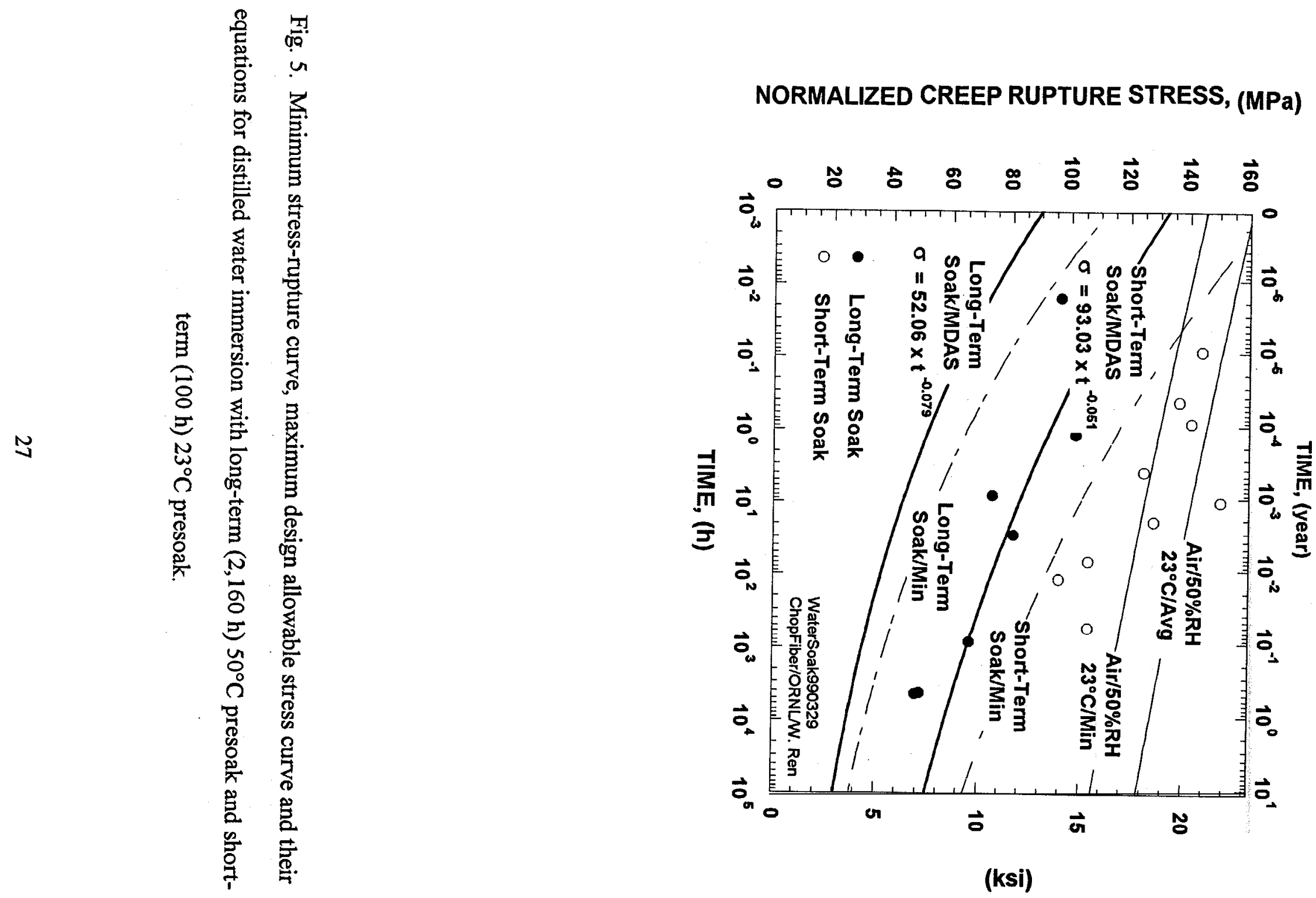


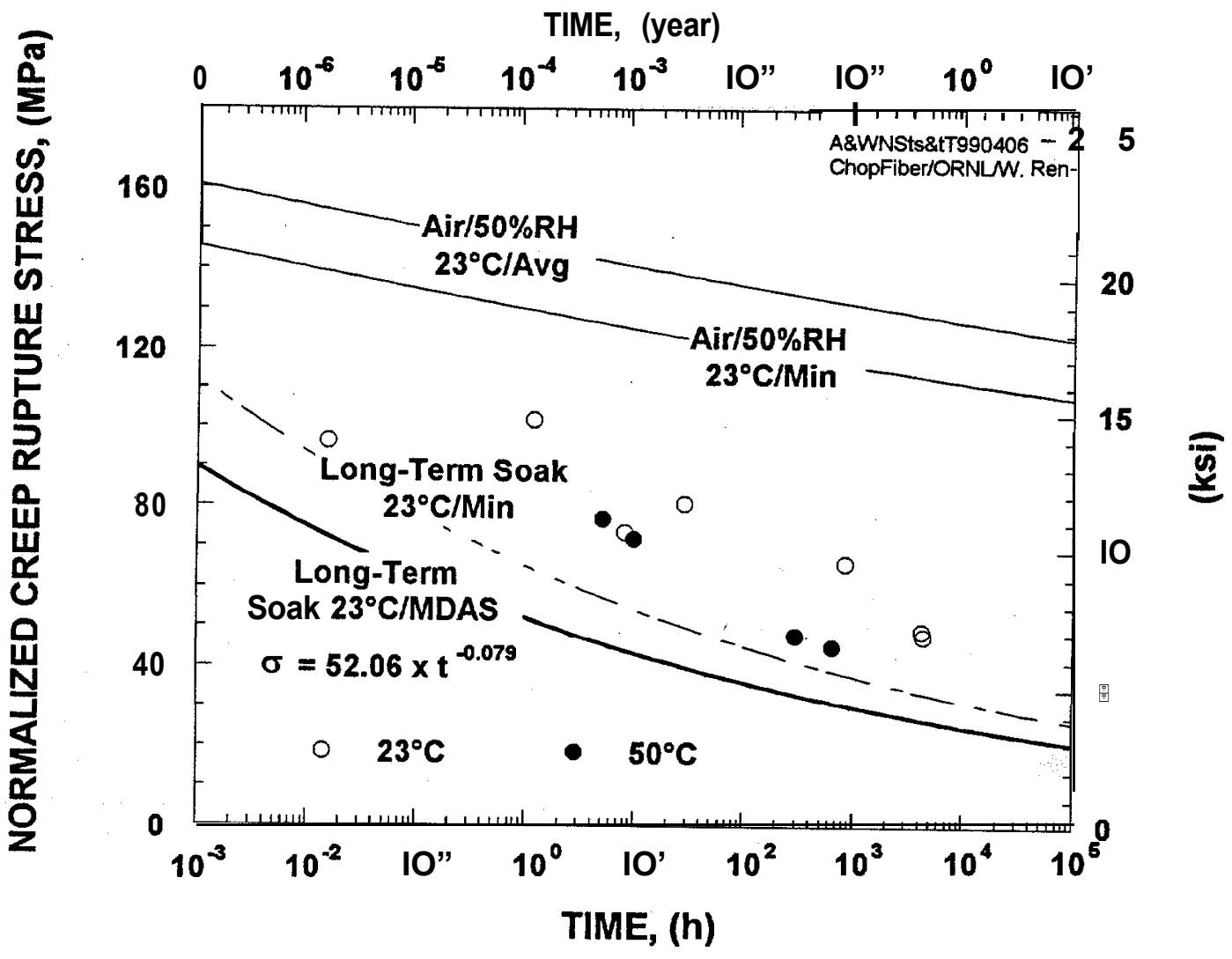

Fig. 6. Effect of test temperature and water on stress-rupture strength of specimens with a 3 month $50 \mathrm{C}$ presoak. 


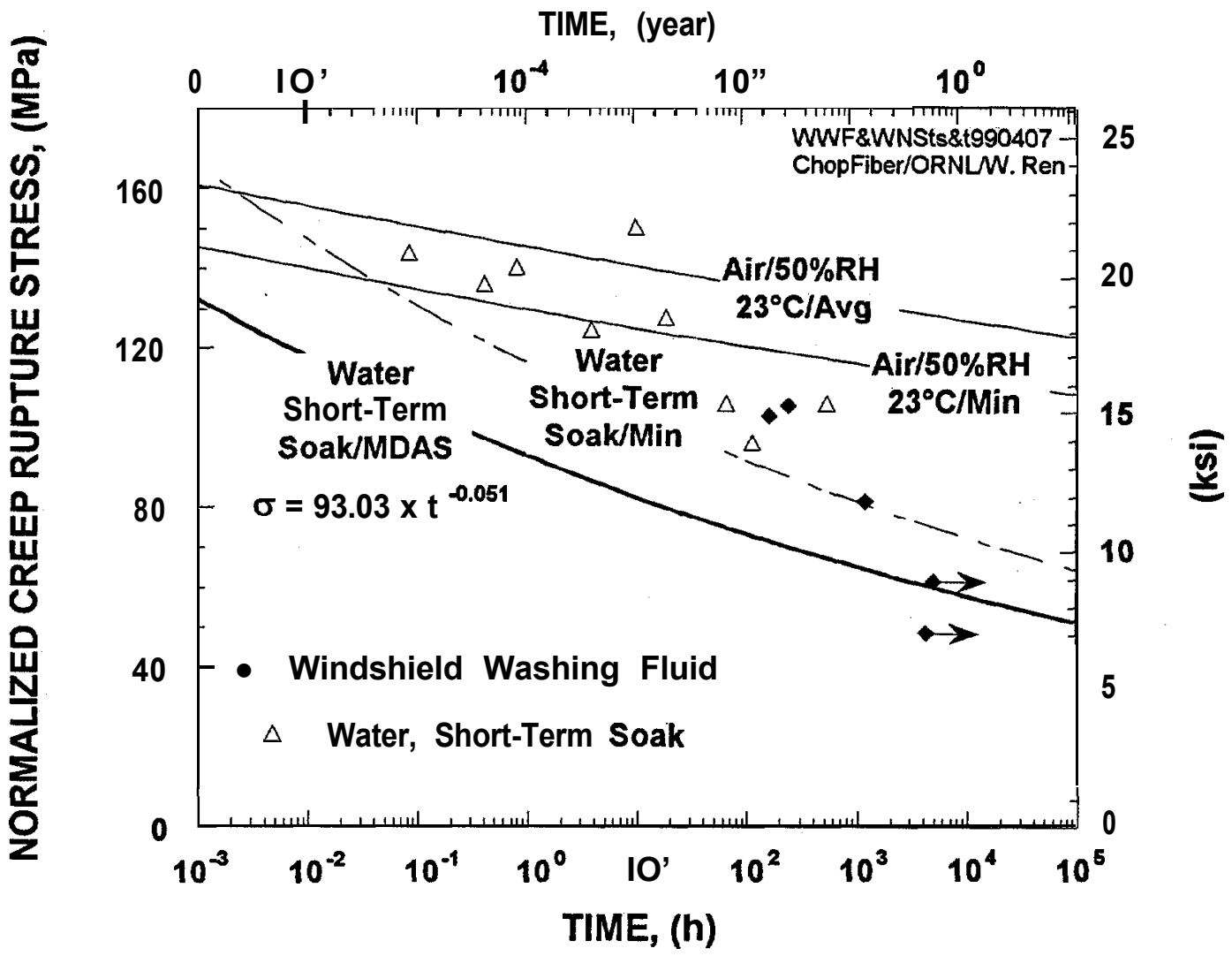

Fig. 7. Effect of windshield washer fluid on stress-rupture strength compared to short-term soak distilled water effect. 


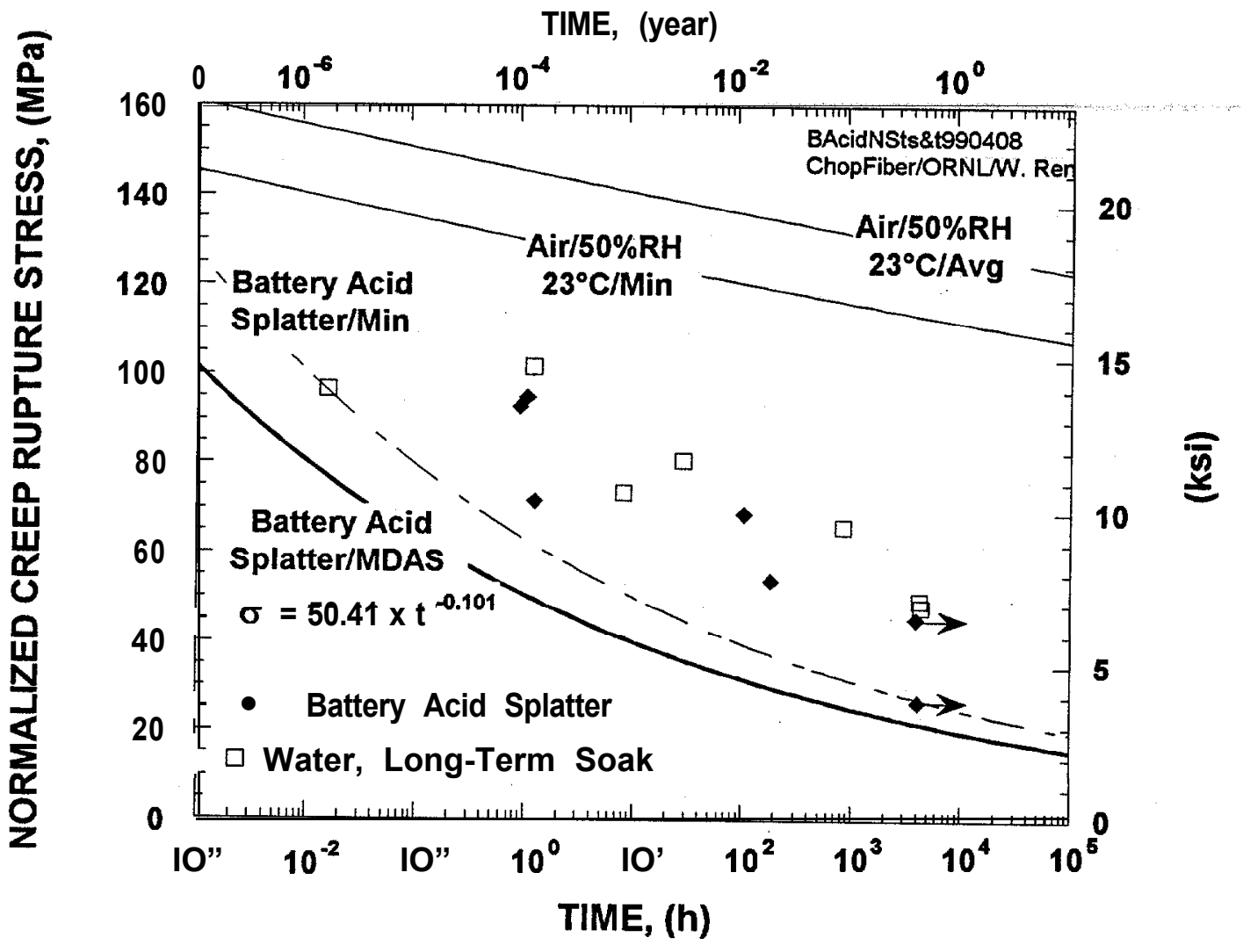

Fig. 8. Effect of battery acid splatter on stress-rupture. 


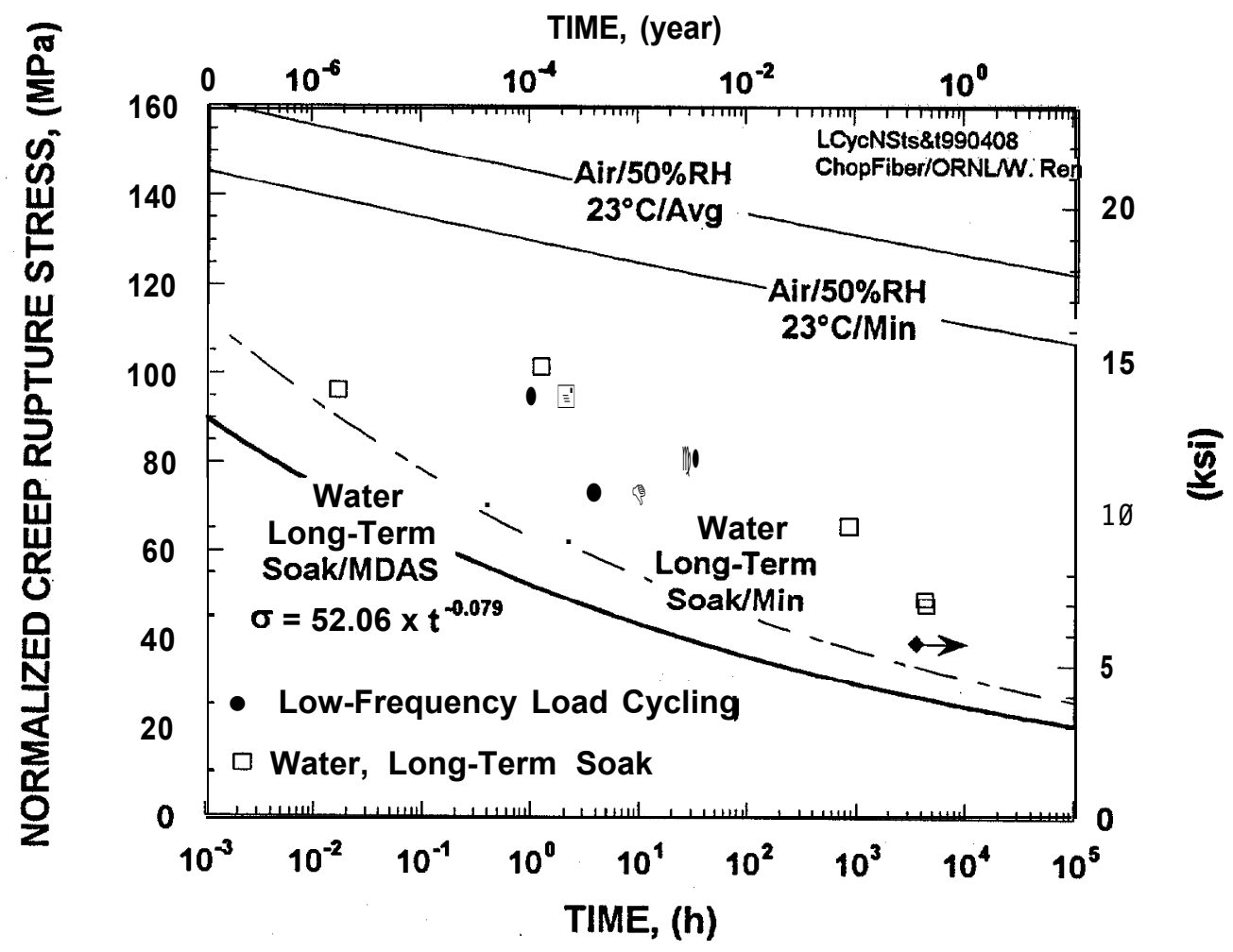

Fig. 9. Effect of low-frequency load cycling in Air/50\%RH23 $\mathrm{C}$ on stress-rupture. 


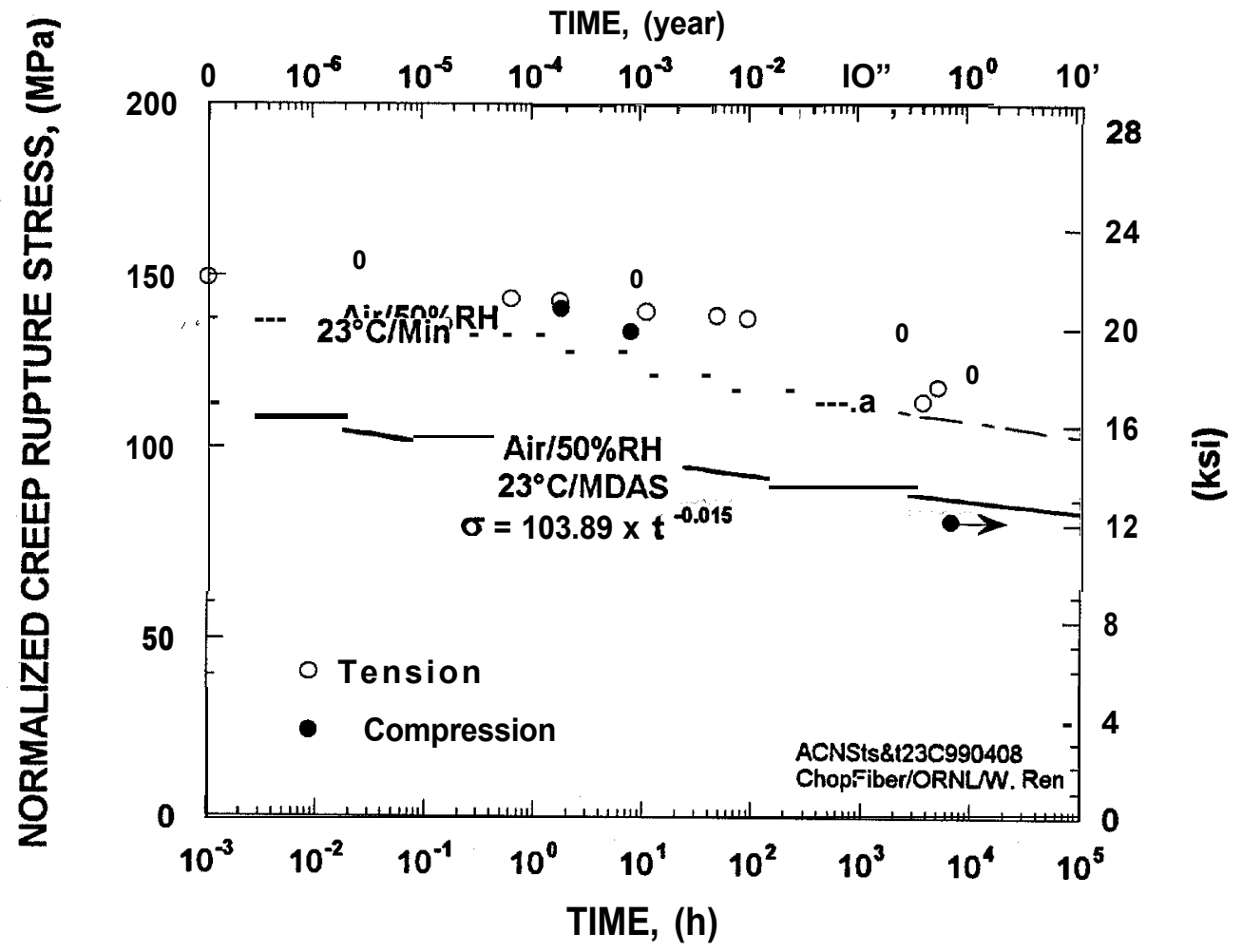

Fig. 10. Stress-rupture behavior under compression in $\mathrm{Air} / 50 \% \mathrm{RH} 23^{\circ} \mathrm{C}$ compared to that under tension. 


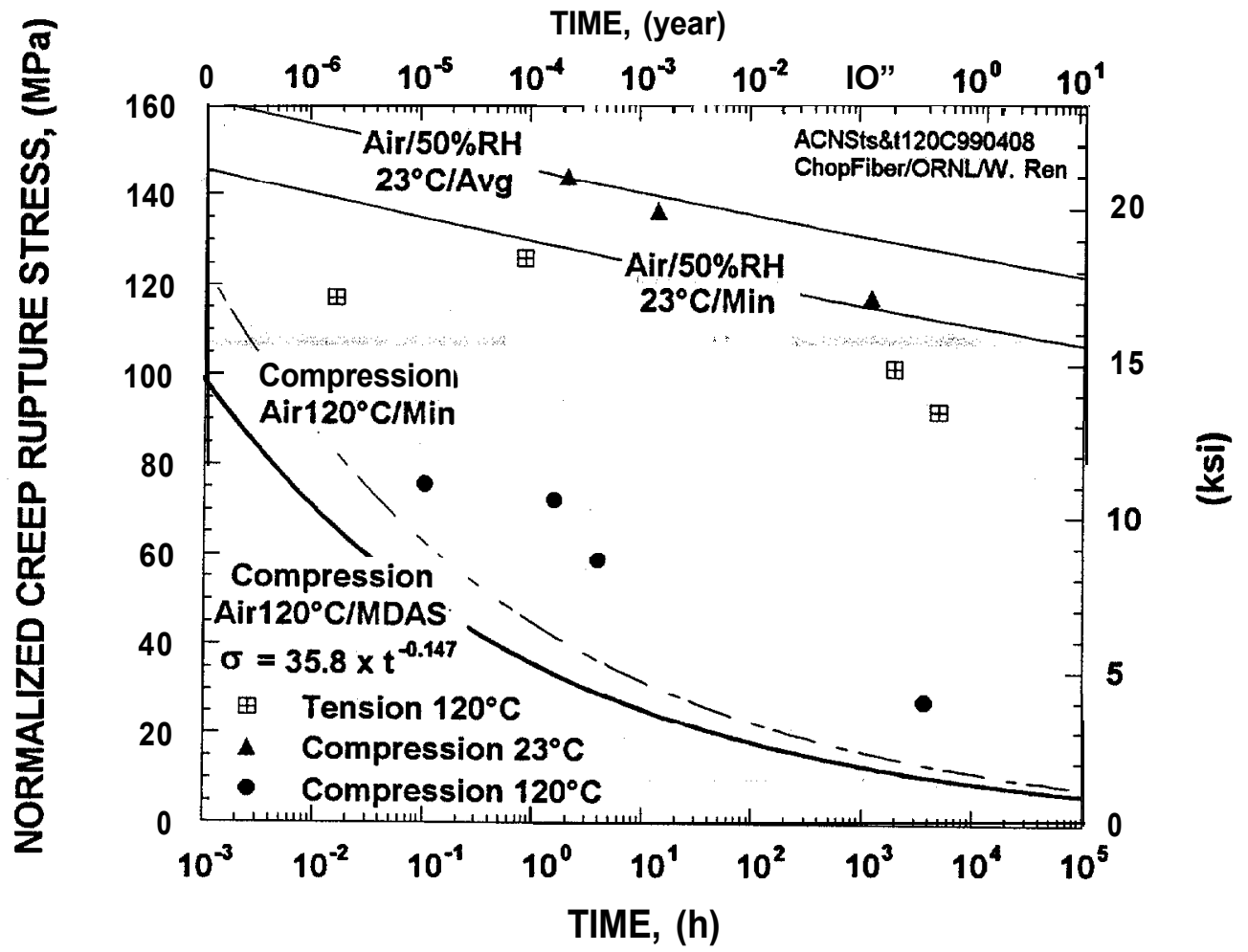

Fig. 11. Stress-rupture behavior in air under compression compared to that under tension. 


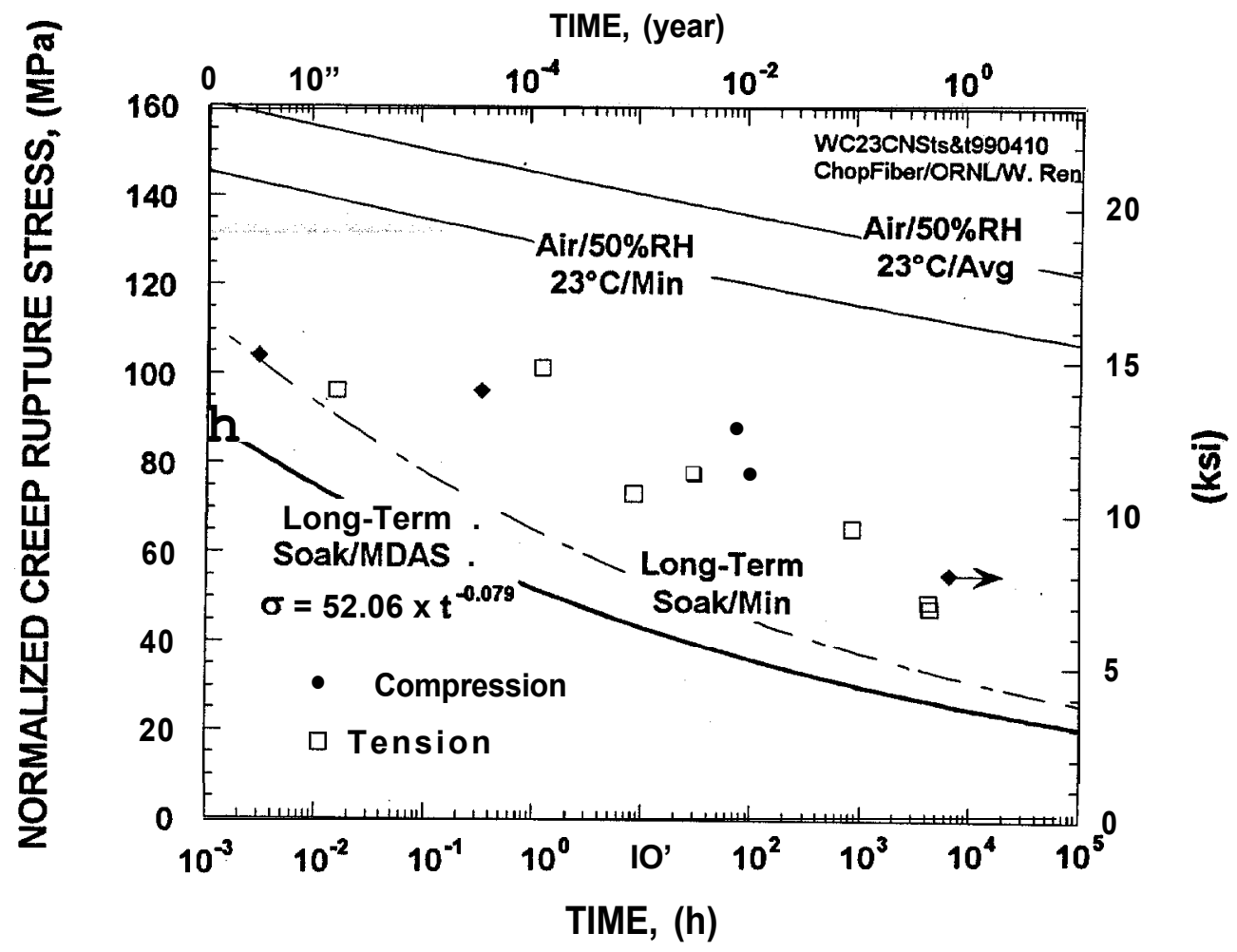

Fig. 12. Compressive stress-rupture strength in water at $23^{\circ} \mathrm{C}$. The minimum stressrupture curve, maximum design allowable stress curve and its equation for tension are applicable for compression. 


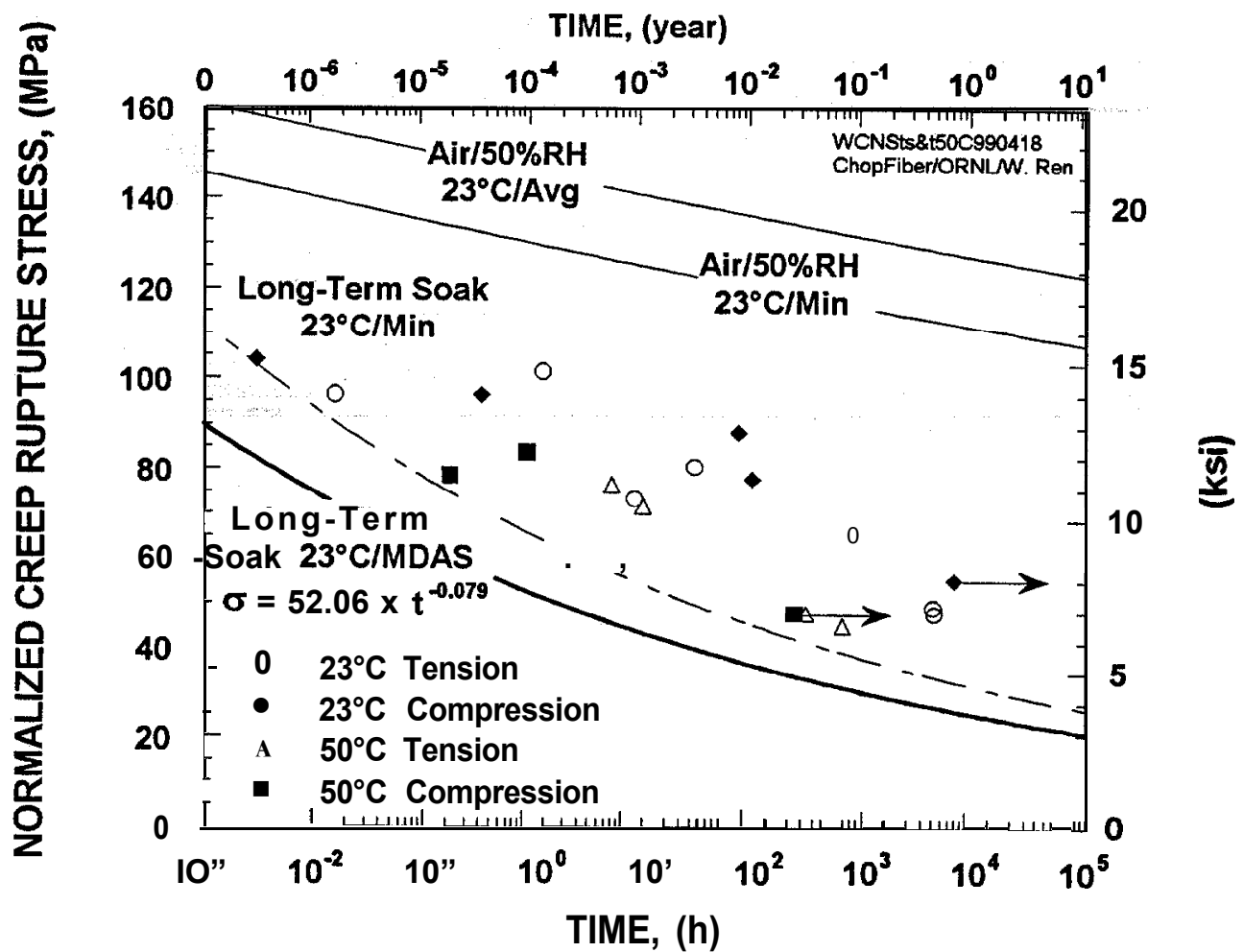

Fig. 13. Compression at $50^{\circ} \mathrm{C}$ in distilled water. All the data points are still bounded by the minimum curve for tension at $23^{\circ} \mathrm{C}$. 


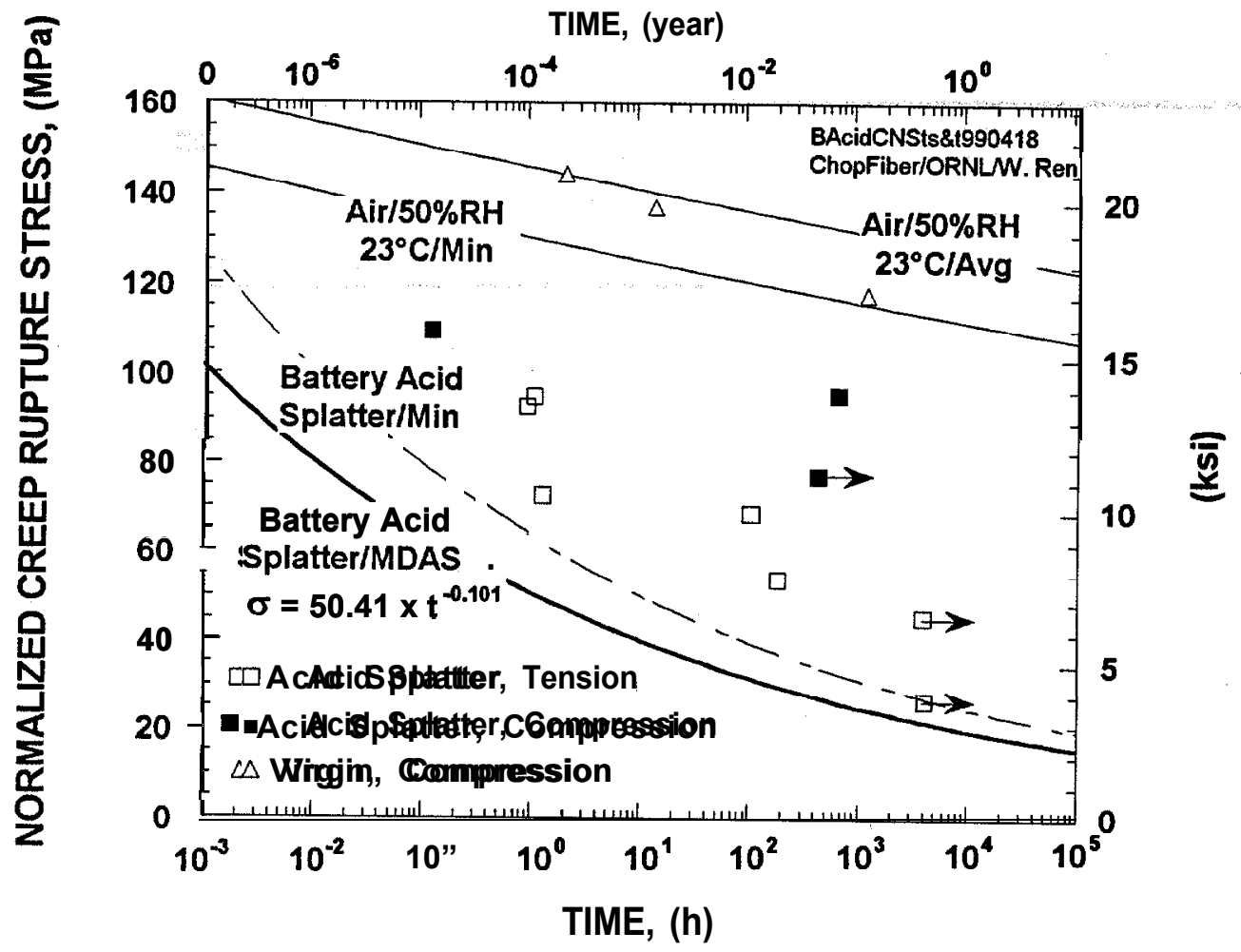

Fig. 14. Effect of battery acid splatter on stress-rupture 


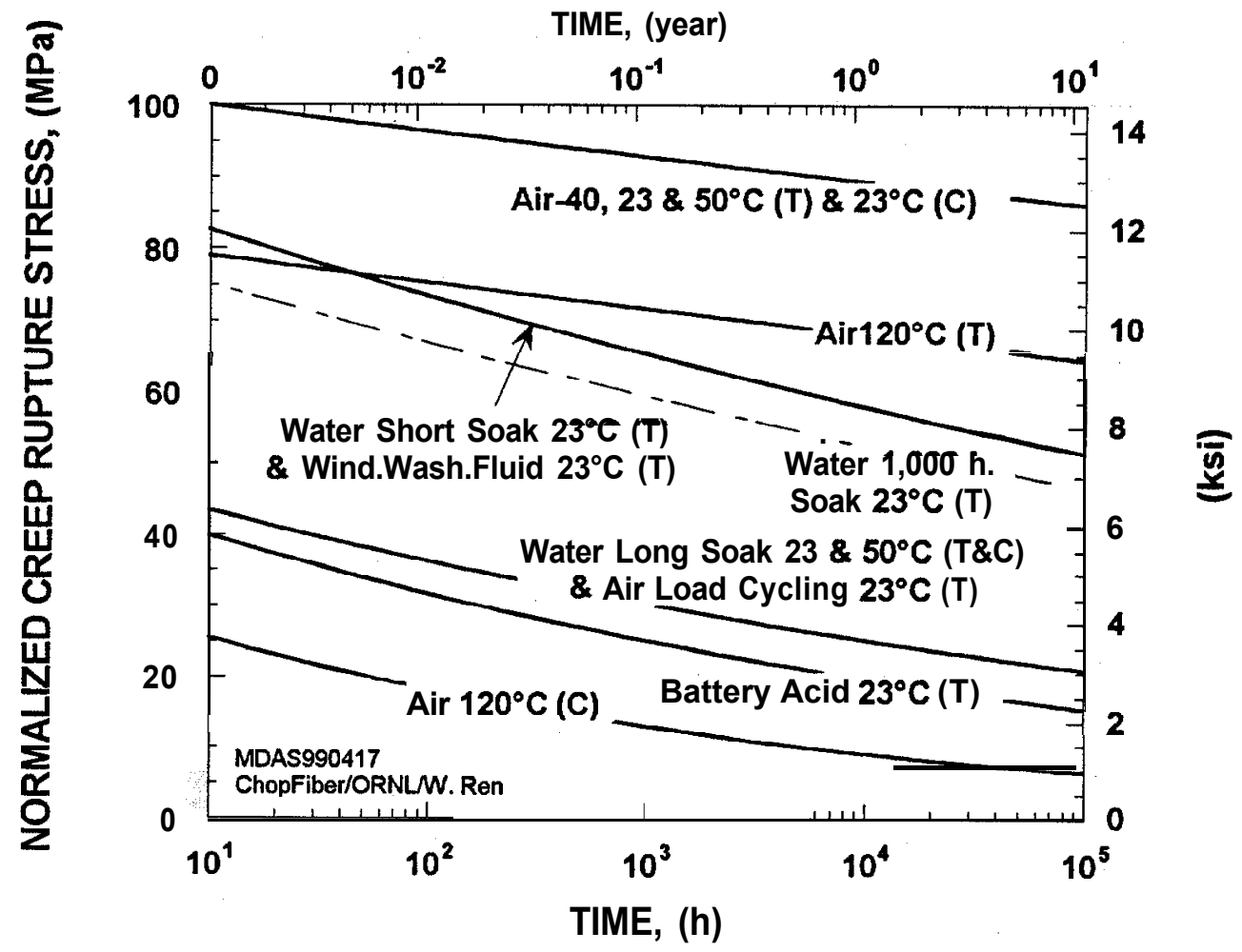

Fig. 15. Maximum design allowable stress curves in various simulated automotive environments. The dash curve is a prediction. 


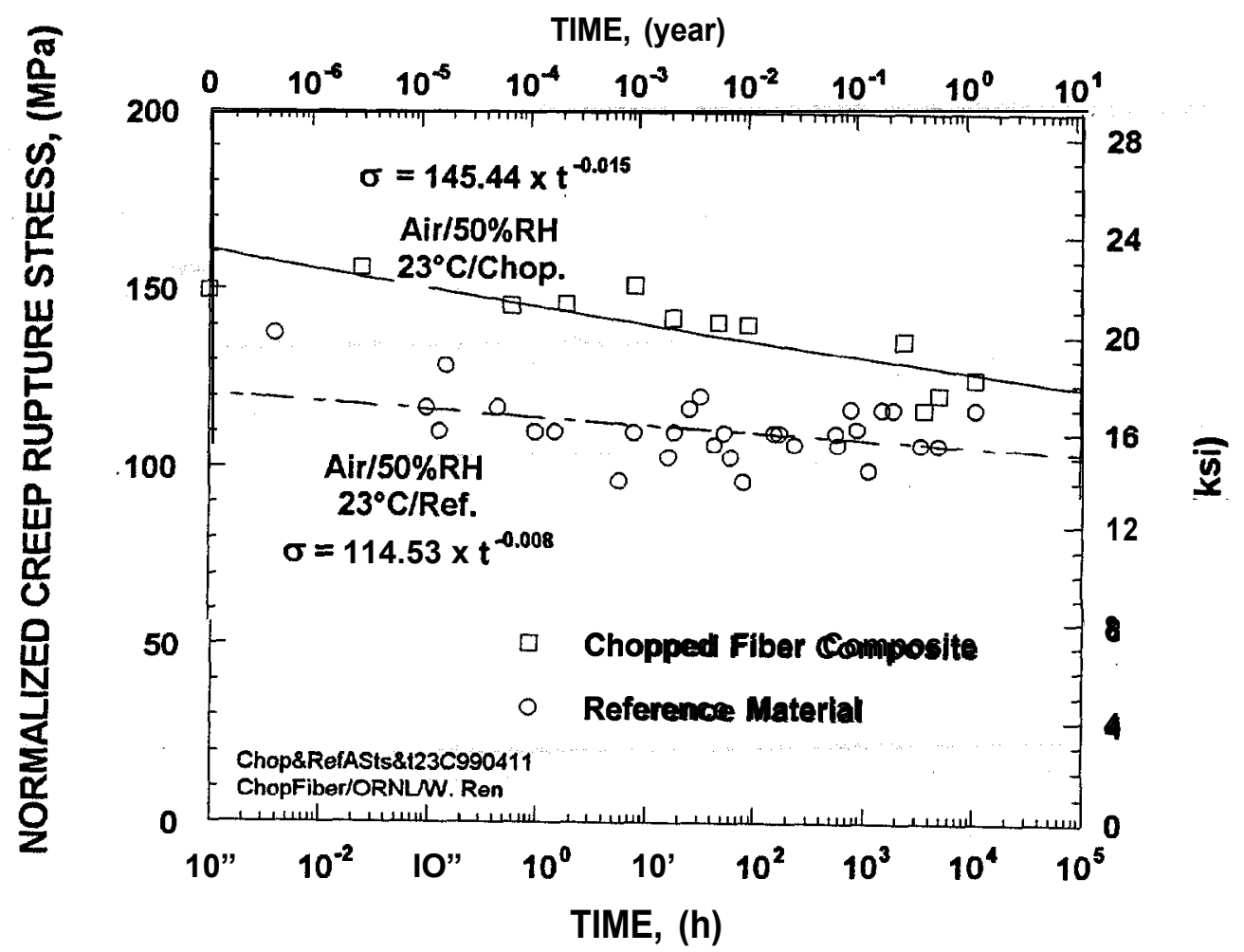

Fig. 16 Comparison between stress-rupture data for the chopped-fiber composite and those for the reference material in the baseline condition. 


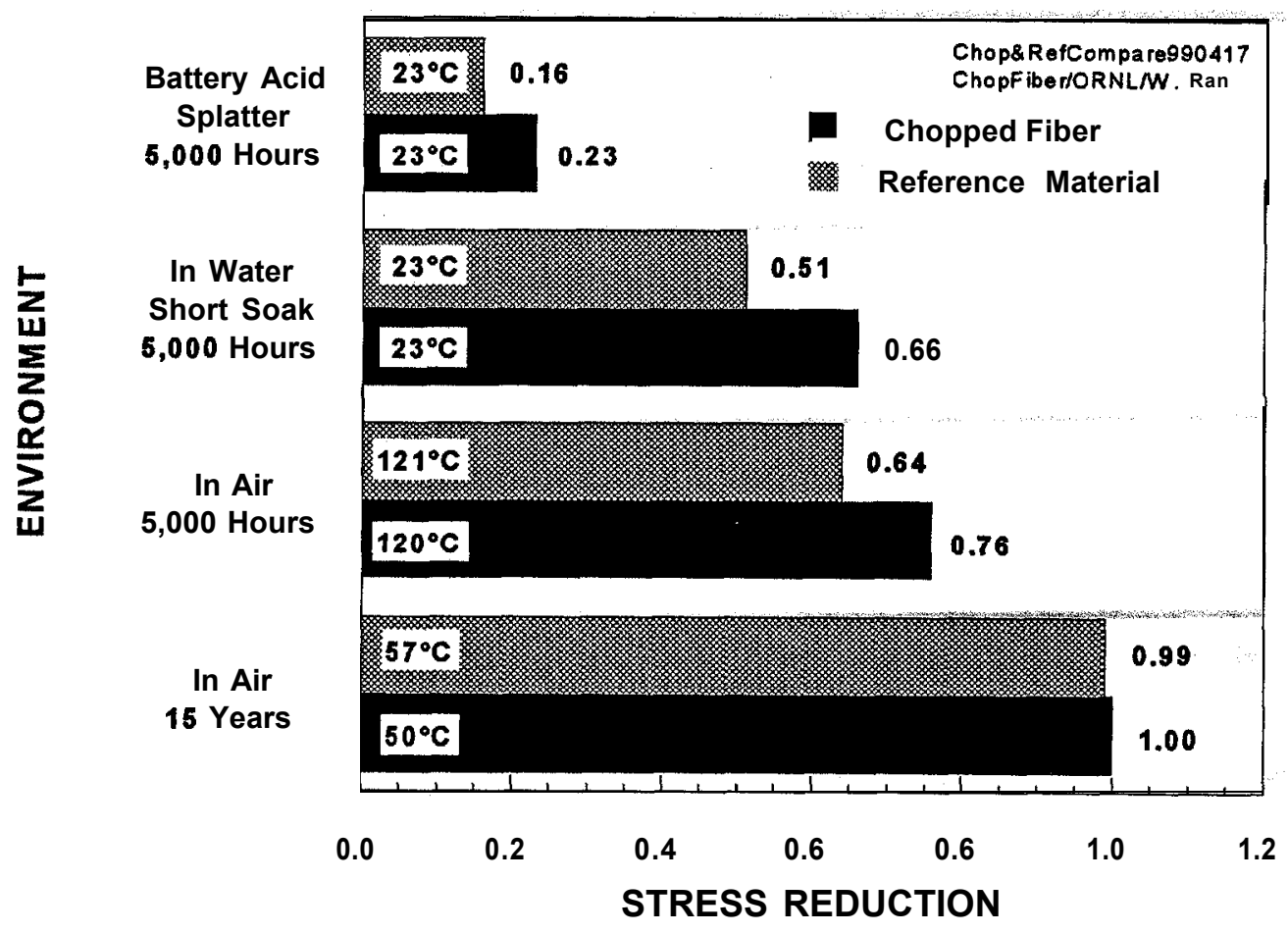

Fig. 17. Stress reduction for the chopped-glass-fiber and the reference material in the representative environments based on the respective maximum design allowable stresses in $\mathrm{air} / 50 \% \mathrm{RH}$. 